\title{
AS I SEE IT
}

\section{The erosion of academic freedom in UK higher education}

\author{
Anna Traianou* \\ Department of Educational Studies, Goldsmiths, University of London, New Cross, SE14 6NW, UK
}

\begin{abstract}
In this article, I treat 'academic freedom' as referring to the autonomy that academics need if they are to do their work well, on analogy with what is required in other professional occupations. In these terms, I argue that there are 2 aspects of academic freedom: the degree of autonomy that universities have from governments, and the autonomy that academics have within universities. Using this framework, I explore how, from the 1980s onwards, UK governments have increasingly intervened in higher education, on the basis of the assumption that universities must serve the economy, seeking to maximize and measure the 'returns' on public investment. I argue that these external developments have promoted internal changes within universities away from collegial modes of organization and towards more managerial ones, and as a result have significantly reduced academic freedom. I conclude by briefly examining developments in the UK in terms of a rather different conception of academic freedom, one that is currently quite influential, which virtually identifies it with 'free speech' for academics and students.
\end{abstract}

KEY WORDS: Academic freedom - Neoliberalism - New public management - UK higher education $\cdot$ Professionalism $\cdot$ Free speech

\section{INTRODUCTION}

Academic freedom in the UK is a contentious matter, as it is elsewhere, and it has long been so. In the 1960 s and 1970s, it was a slogan that was loudly deployed by both Left and Right. Leftist student radicals of the late 1960s were charged by Rightwing commentators with breaching academic freedom by preventing or disrupting meetings that hosted speakers to whom they objected. At the same time, the Left also complained of offences against academic freedom, for example when they believed that Left-wing applicants for academic jobs had been rejected because of their political beliefs (see Arblaster 1973). Appeal to the principle of academic freedom continues to be made today across the political spectrum, for example on both sides of the debate about whether US and UK academics should boycott Israeli universities, at least those

\footnotetext{
${ }^{*}$ Corresponding author: a.traianou@gold.ac.uk
}

which have not opposed the siege of Gaza (see Butler 2006, Goldberg 2013, Robin 2014). The concept is also central to debates about the extent to which various kinds of Muslim radicalism or anti-migrant English nationalism should be tolerated on campuses, with 'No platform' arguments on one side and arguments for unconstrained academic freedom on the other (Hayes 2009).

Academic freedom continues to be a principle to which there is wide appeal. However, it has been interpreted in a variety of ways (Arthur 2006), and indeed it amounts to an essentially contested concept (Collier et al. 2006). Thus, in his introduction to an influential collection of essays on academic freedom, Menand (1996) argued that it has always been problematic, and perhaps is inherently problematic.

In fact, there are 2 very different conceptions of academic freedom to be found in the literature. Some commentators effectively treat academic freedom as

() The author 2015. Open Access under Creative Commons by Attribution Licence. Use, distribution and reproduction are unrestricted. Authors and original publication must be credited. 
equivalent to free speech: the freedom of academics and students to speak out on public issues, without attempts to prevent this and without their being penalized for doing so. This relates to public statements as well as to the presentation of personal views in the course of teaching sessions, or in research publications. For example, in the UK, an influential definition of the term was provided in an amendment to the Education Bill of 1988, as part of an attempt to ward off the damaging effects on universities of this piece of proposed government legislation (which was eventually passed in modified form). This definition claimed for academics:

\begin{abstract}
...the freedom within the law to question and test received wisdom, and to put forward new ideas and controversial or unpopular opinions without placing themselves in jeopardy of losing their jobs or privileges they may have at their institutions (Russell 1993, p. 1-2).
\end{abstract}

By contrast, other writers interpret academic freedom to refer to a form of professional autonomy, relating to university academics as an occupational group. Thus, Haskell (1996, p. 54) declared that '...the heart and soul of academic freedom lie not in free speech but in professional autonomy and collegial self-governance'. Here, the main emphasis tends to be on the need for considerable autonomy in the spheres of research and teaching (Post 2006, Fish 2014).

For the most part, here I will adopt the second of these 2 conceptions of academic freedom, since it is in these terms that the most significant changes have taken place in the UK. From this point of view, the term refers primarily to the discretion that academics must be able to exercise in order to do their work well, in relation to both teaching and research. It parallels the discretion that other professions also need, and are able to exercise to one degree or another (see Shils 1997). Of course, 'profession' has also become a contested concept, one that has increasingly been rejected or redefined. Interestingly, in the second half of the 20th century, criticism of the notion of professionalism came from both Right and Left, and from both economists and sociologists: it was portrayed as little more than an ideology designed to exert illegitimate control over clients, thereby restricting market competition and blocking democratic accountability (Larson 1977, Freidson 1983, Broadbent et al. 1997). Furthermore, there are respects in which the position of academics does not match the traditional model of a profession, which in its original form involved commercial independence of individual practitioners, or at least of the practices in which they engage, in supplying a service to a specific clientele.
As a result of increasing criticism of the concept of professionalism, and of changing economic and political circumstances, in the UK and other Western societies many occupations claiming professional status have been subject to encroachment on their autonomy, especially where they formed part of the public sector. New forms of public management have been imposed, managerialist in character, designed to establish 'transparent' accountability regimes which require members continually to demonstrate that what they do is effective and efficient (Pollitt 1990, Power 1999, Ward 2012).

These changes have affected universities, with significant consequences for academic freedom. There have been 2 relevant areas of change that are closely interrelated: the relationship between universities and governments or other sources of funding; and the relative autonomy of faculties, departments, research groups and, above all, individual academics within universities. I will look at each of these aspects in turn.

\section{THE AUTONOMY OF UNIVERSITIES}

In the UK, as well as elsewhere, the history of the relationship between universities and the state is complex and changing (see Russell 1993, Collini 2012). However, in general in the past, universities operated under arrangements where, despite broad constraints and periods when there were major interventions, they were able to exercise considerable autonomy from religious, commercial and governmental pressures. Even where they were religious foundations, much of the time there was considerable scope for unorthodox views. Where they were private foundations, they were not usually run 'for profit'. And, even though they often served a vocational function, this was usually framed as a matter of providing a liberal education. This was characteristic of ancient foundations like Oxford, Cambridge, and Aberdeen, but it was also true of the universities founded in the 19th and early 20th centuries. Moreover, this idea of university autonomy continued to be influential even after university funds started to come primarily from central government (Russell 1993).

Nevertheless, we can trace a trend even from the 1950s away from this model of what might be called patronage funding towards an investment model, although it gathered pace considerably in the 1980s. This change had 2 aspects, with government seeking to play a more interventionist role in relation to the 
organization and practice of universities, and at the same time encouraging universities to operate more in the manner of commercial enterprises, responding to new demands and opportunities, and securing external funds so as to reduce the proportion of their finance coming from taxation. These changes partly stemmed from the growing size of the university sector and the considerable demands that it placed upon public finances, but it also resulted from periods of economic austerity, and from important ideological and political changes in the UK (Jones 2015).

A significant early political development was the Report of the Robbins Committee on Higher Education of 1963, which recommended the expansion of higher education. As a result, in the 1960s and 1970s, higher education expanded rapidly, being transformed from an 'elite' into a 'mass' system that was highly diversified. At one end of the spectrum were a small number of universities, including Oxford and Cambridge with their longstanding connections to the system of private schooling (Scott 1995). At the other end, after the abolition of the distinction between universities and polytechnics through the Further and Higher Education Act of 1992, there emerged a considerable body of lower-status universities that struggled to improve their reputations and funding in relation to the 'redbrick' universities established earlier in the 20th century, and the newer ones of the 1960s whose establishment had been stimulated directly by Robbins (1966). Undergraduate student numbers within most universities also grew considerably over the course of the second half of the 20th century, from 111111 in the 1960s to 1803840 in 2012/13 (Higher Education Statistics Agency: www.hesa.ac.uk/stats).

From the 1970s onwards, there was also a significant shift in the approach of Government towards universities. Even though he was an economist, Robbins had seen the role of university education in social and cultural, as well as economic, terms. Universities should teach skills, but also produce 'cultivated men and women', promote the 'advancement of learning' and foster 'common standards of citizenship' (Robbins 1966, p. 6-7). However, emphasis increasingly came to be placed upon the economic function of universities. The oil crises of 1973 and 1979 prompted significant cuts in university funding, as in other parts of the public sector. The result was that in the 1970s, the value of grants to students fell by $10 \%$, as did the purchasing power of academics' salaries (Radice 2013, see also Shattock \& Berdahl 1984, Sizer 1987). The economic austerity propelled the Conservative governments of Margaret Thatcher
(1979-1990) into a remorseless pursuit of 'efficiency', aimed at a steady reduction in the costs per student.

At the same time, there was also a change in political attitude towards government funding of the public sector, including the universities. This can be characterized as a move towards treating education as an investment in human capital, requiring it to display economic returns. Thus, the 1988 Education Act introduced a 'vast new machinery designed to make universities more "accountable" for the public money they received' (Russell 1993, p. 7). The Act also abolished academic tenure, with the idea that this would open up the way for rationalization within universities, including the closure of some departments, to increase efficiency. This led to considerable opposition. For example, in 1981, vice chancellors joined demonstrations against cuts to university funding, and in 1985, the Congregation of Oxford University refused to grant the then Prime Minister, Margaret Thatcher, an honorary degree (see http:// news.bbc.co.uk/onthisday/hi/dates/stories/january/ 29/newsid_2506000/2506019.stm).

Thus, UK Government increasingly began to view the purpose of higher education in economic terms, i.e. that it should be directed towards meeting the needs of the economy. As a result, since the early 1980s the state has increasingly been involved in shaping the character of universities, with this aim in mind. Furthermore, these trends were strengthened during the subsequent years of New Labour government (1994-2010). Policies were framed in terms of the demands of globalization and the shift to a 'knowledge economy', which required an upgrading of the knowledge and skills of a large proportion of the population. This led to further increases in the number of students going to university, with the target being set at a $50 \%$ participation rate.

Like the Conservatives, New Labour argued that the state could not bear the entire costs of the expanded system. As a result, there was pressure for university researchers to build close relationships with industry and thereby secure greater private funding. In addition, fees for students from outside the European Union were greatly increased. Later, even more consequentially, it was decided that UK students should now be charged tuition fees, with a student loans scheme set up to facilitate this. From this point onwards, students were increasingly positioned as 'customers', whose satisfaction must be maximized. Competition amongst universities was encouraged. The establishment of the National Student Survey in 2005 designed to measure 'student satisfaction' (see www.thestudentsurvey.com/), the 
annual publication of league tables, across both teaching and research, was indicative of the competitive climate that developed. At the same time, there was also increased governmental control, for example through the development of Quality Assurance procedures (see www.qaa.ac.uk/en).

When tuition fees for home students were introduced in 1998, institutions were allowed to charge up to $\mathrm{E} 1000$. In 2004 this maximum was increased to $£ 3000$. Then in 2010, in the aftermath of the 2008 economic crisis, the Coalition Government increased the cap on fees to $£ 9000$. Alongside this, government funding for the teaching of arts, humanities and social sciences undergraduate degrees was withdrawn. In addition, the way was opened up legally for the entry into the system of private-for-profit colleges, and these have proliferated in the past $5 \mathrm{yr}$, increasing commercial pressures on conventional universities (McGettigan 2013, 2014).

Unlike in the 1980s, when Vice-Chancellors opposed government intervention over the funding of the higher education system, those in post during these more recent changes adopted a 'pragmatic' stance and, in effect, provided very little resistance to the new funding system. Most have argued that accepting these changes is necessary or even beneficial. For example, the view of Sir Steve Smith, President of Universities UK, was that:

This is a radical shift that is driven by a clear political aim: to introduce more market incentives into the system. Those market drivers mean that universities have to be clear about what we offer: that is, a high-quality product, provision of skills and experiences that will directly benefit the student, and adding real value to them as individuals as they go through life (Smith 2011, p. 135).

Equally important have been changes in the policies of external funding bodies, notably the Economic and Social Research Council (ESRC), one of the 7 UK research councils which dispenses public funds for research. There has been a shift towards a much more interventionist approach, both in prioritizing research topics and in relation to the organization of postgraduate research training. As a result, a growing proportion of funding is now provided through invitations requiring researchers to compete for funds to investigate specified topics, as opposed to the earlier emphasis on a responsive funding model where researchers decide which topics are worth investigating and are viable. Moreover, there is increasing pressure from ESRC for research to be directed towards practical application by external users. This is part of a broader demand that researchers maximize the 'impact' of their work.
Thus, over the past $30 \mathrm{yr}$, public sector expenditure has increasingly been conceptualised in economic terms. Education has come to be viewed as an 'investment' in which a 'return' should be expected and should be demonstrable. This has had dramatic consequences for universities. There has been increased government intervention, reducing their autonomy. Holmwood (2010, p. 640-641) explained that the changes introduced into the UK higher education system are associated with neo-liberal forms of governance which 'seek to manage public activities by finding proxies for market mechanisms'. It is assumed that market forces guarantee 'efficiency' and that setting up systems that mimic these is essential to maximize the return on public investment. On the teaching side, the principle of free higher education has been abolished. This has led to the increased commercialization of universities: they have come to be driven by competition with one another for students, and are seen primarily as representing a competitive hierarchy in terms of how successful they are in producing graduates for high-level occupational positions. As regards research, there has been a significant shift towards non-governmental funding, and the funding available from government has increasingly been targeted in areas that are believed to be national priorities.

This restructuring of the relationship between government and universities was transformative: it combined increased regulation with marketization. The effect has been a reduction in the autonomy of universities from governments and other sources of funding, and increased commercial pressures. This has had a significant effect on the internal organization of universities, and thereby on the autonomy of academics.

\section{THE AUTONOMY OF ACADEMICS WITHIN UNIVERSITIES}

There is no automatic correspondence between the autonomy of universities and the autonomy of academics: conceivably, universities could operate as autonomous organizations yet allow academics little discretion in doing their work. Indeed, where university autonomy takes a commercial form, this is very likely to be at odds with the autonomy of individual academics. Yet, historically, there has been a close connection between these 2 aspects of academic freedom, and they have often been seen as mutually beneficial. Erosion of the traditional form of university autonomy, outlined above, has significantly 
affected the conditions in which individual academics work.

Broadly speaking, the result has been a shift from internal organization of universities on a broadly collegial model towards a managerial mode of operation. In 1992, reporting on the changes occurring then, Tapper \& Salter (1992, p. 11) noted how previously university autonomy and academic freedom had been seen as 'an essential pre-condition for the disinterested search for knowledge and for the preservation of those values on which a civilized society depends'. More recently, what they are seen to protect is the production and dissemination of a distinctive kind of knowledge, with this contributing to the quality of discussion in the public sphere (Post 2006). Middlehurst (2004, p. 260) outlined the previously prevailing form of collegial organization, as follows:

the model of internal governance [...] was one in which academic authority was supreme, expressed operationally in terms of management and decision-making through committees, with senior academics chairing the committees. The purpose of the committees was to achieve consensus about the direction and functioning of the institution across the range of different academic interests, and to maintain this over time. Thus committees needed to represent the range of disciplines and academic functions, to have overlapping membership so as to co-ordinate across functions and to have a turnover of office-holders. The aim was for procedures to be orderly, judgements to be carefully weighted and broad consultation to be undertaken.

From the mid-1980s onwards, there were increasing efforts by government to bring business management structures and decision-making processes into higher education, with a move towards stronger central executive management (see Middlehurst \& Kennie 1995). As already noted, the new model was close to what has been referred to as 'the new public management', or managerialism (McNay 1995, Pollitt 2003, Ward 2012).

A key change in universities has been a strengthening of the role of Vice Chancellor, which is now being seen as equivalent to the Chief Executive of a multi-million pound business, whose task is to lead strategic change. This has resulted in significant modifications to recruitment processes, including sometimes recruitment from outside the academic sector. The roles of Deputy and Pro-Vice Chancellors have also become more significant, becoming fulltime appointments, with incumbents leading managerial teams responsible not just for teaching and research but also for external relations and community engagement, 'knowledge transfer', etc. Furthermore, directors of finance and of human resources are usually key members of Senior Management Teams. Thus, at the highest level of the organization, the service functions of Planning, Estates, Finance and Human Resources are likely to be represented as well as the academic functions. There have also been internal re-organizations in many universities resulting in larger academic units, often with a view to achieving 'economies of scale' in infrastructure costs. Within the new internal accounting systems, these units are subject to performance targets, outcome measures and audit mechanisms, providing a supposedly transparent form of governance parallel to those in other publicly funded institutions and in commercial companies (see Power 1999, Strathern 2000).

In these ways, the older collegial system of professorial organization has been replaced by a managerial hierarchy based upon functional control. This has led to increased centralization and a reduction in the autonomy of faculties, departments and individual academics. It has been noted that, in making these changes, 'universities are not adapting to the requirements of effective knowledge production as judged by some "intrinsic" standard... but to the policies and practices of the particular form of funding of higher education. In the name of becoming more efficient and flexible organisations, universities have become more centralized-evident in the replacement of Senate by Executive Boards - and bureaucratic, in order to direct the university's activities to meeting a few, simplified proxy targets' (Holmwood 2010, p. 641).

These changes parallel similar developments relating to other professions, and the organizations in which they work. In particular, the National Health Service in the UK has changed from being run by doctors, effectively, to being under the control of managers working more or less directly under policies laid down by the Department of Health. As a result, the work of doctors has become much more constrained than it was in the past. Much the same is true of other professions operating within the public sector.

The internal organizational changes within universities have affected both teaching and research, imposing de facto significant constraints on academic freedom. In the past, what courses were to be taught was decided by departments, and largely in terms of what was thought to be important in disciplinary terms and in light of the specialist research areas of members of the department. Today, however, decisions about the curriculum are more centralized, at the Faculty level and sometimes even higher up the 
managerial hierarchy, and are strongly determined by concerns about financial return, particularly the numbers of students likely to be attracted and their retention. A striking example of the effects of this was the decision taken by Middlesex University in 2010 to close its Philosophy department, in order 'to concentrate its resources in areas where a better return is available' (Wolff 2010; see also McGettigan 2013). As noted earlier, the marketization of undergraduate courses has been accompanied by a view of students as 'customers', concerned primarily with their future employment and choosing courses which will secure this. Partly as a result of this change, with many parents playing an increased role in funding their children's education, students are also seen as vulnerable, as in need of protection by the government. Hayes (2009, p. 142) described this as the 'infantilization of young people':

They are treated as if they were still in the primary school. They are welcomed with their parents, they are recommended counseling courses to help them in the transition from school, courses in coping with stress and examinations. They face not challenging ideas but an army of 'support services' all re-enforcing institutional and subjective perceptions of vulnerability.

In this distorted version of university education it is seen as incumbent on academic staff to develop a curriculum suited to the 'needs' of students for securing the jobs which they aspire to, as well as satisfying them, their parents and the government that value for money is being supplied (see Scott 1987, Holmwood 2011).

The changes in the internal organization of universities have also effectively devolved financial risks to the level of academic departments and individuals. This has created a climate in which both insecurity of employment and intensification of work increased: by 2009, $34 \%$ of British academics worked on temporary contracts of one kind or another (Jones 2015). Their work and that of those on more permanent contracts is monitored, assessed and controlled. One example of this is the costing methodology known as Transparent Approach to Costing (TRAC), which purports to show the distribution of academics' activity across teaching, research and other tasks, and therefore how much each costs. McGettigan (2013, p. 186) suggested that this means that academics are now treated as 'frontline delivery staff, an overhead to be reduced'.

Paralleling this, there are increasing attempts strategically to manage research, to boost the attraction of external funds and performance in the Research Excellence Framework (REF, an exercise which takes place every 6 yr in order to determine the allocation of research funds among universities in the UK, purportedly assessing the 'quality' of the research produced, see www.ref.ac.uk/). One result of this is that research is increasingly being geared entirely towards obtaining external funds and producing sufficient 'outputs' of the right kind for REF. As a consequence, many academics are pushed towards relatively mediocre activity that will allow them to obtain funds and produce the necessary publications within the assessment period, rather than engaging in longer-term projects whose products might be of more value: 'REF scores increasingly drives what is researched, how it is funded and where it is published' (Sayer 2014a; see also Sayer 2014b).

Another aspect of strategic management of research has been the growth of ethical regulation within universities (see Hammersley \& Traianou 2011, 2012). In the UK, this is largely a result of ESRC's Research Ethics Framework (2005) and Framework for Research Ethics (2010), which demand that most, if not all, research proposals be subject to vetting procedures before they can be funded. Ethical regulation of this kind - extending beyond the codes of professional associations to the exercise of control by institutional ethics committees over what research can be carried out began in the field of health but has spread into other areas of inquiry. This is a development that has particularly sharp consequences for social research, especially qualitative inquiry, because the medical model on which regulatory guidelines and arrangements are based is often at odds with its character. In effect, ethics committees not only judge whether a proposed research project is ethical, but also whether it is worthwhile, and whether the methods adopted are likely to produce valid conclusions. This frequently involves an exaggerated assessment of the ethical risks involved in most social research, and it seriously infringes the professional autonomy of researchers, to the detriment of the pursuit of research. In practical terms, it threatens to prevent particular sorts of investigation, and tends to distort others, thereby shrinking academic freedom and reducing the quality of the knowledge that social science can provide (Hammersley 2009).

\section{CONCLUSION}

I began by noting that academic freedom is a contested concept, and that there are at least 2 rather different senses that can be given to the term. I have treated it as referring primarily to the autonomy that academics need if they are to do their work well, an 
analogy to what is required in similar professional occupations. In these terms, there are 2 key aspects of academic freedom: the degree of autonomy that universities have from governments and other sources of funding; and the degree of independence that academics have within universities. Using this framework, I have explored trends in the UK that have reduced academic freedom. We saw how from the 1980s onwards government has sought increasingly to intervene in higher education, on the basis of an investment model of the function of universities as serving the economy, seeking to measure and maximize the returns on public investment. Equally important, in an attempt both to reduce the relative cost of universities to public finances and to increase their efficiency, measures have been introduced to marketize the higher education sector. Among the most important aspects of this process of marketization is the introduction of student fees, with the effect of turning students and their families into customers whom universities must satisfy.

These external changes have stimulated internal changes within universities, encouraged by government, which have shifted universities increasingly away from collegial modes of organization towards more managerial ones, involving more central control, more setting of targets and monitoring of academics' work. While unlikely to be successful even in their own terms, these changes have nonetheless significantly reduced academic freedom, in terms of the degree of control that academics have over what work they do and how they do it, both individually and as members of departments. All this has been done, of course, in the name of ensuring that universities serve the public and their students; but it is at odds with traditional views of how research can best be pursued and what a good university education involves, and thereby with previous ideas about the public contribution that universities can make.

I want to conclude by reflecting on what has happened in the UK from the point of view of the other conception of academic freedom I mentioned at the start, which focuses on the freedom that academics and students have to express their views. There is a mixed picture here. The developments outlined in this paper have led to more scope for students to express opinions about their courses and their teachers, both through formal procedures and feedback devices, and informally for example on internet sites. There is also scope for academics to express their views in public and to campaign on policy issues, especially if these conform to, or can be made to correspond with, government or university policies, or if they are in line with the purposes of some interest group whose work falls under a relevant policy umbrella, so that assisting them can be labeled 'community engagement'.

However, in other ways there has been a reduction in this kind of academic freedom too, notably where an academic expresses views publicly that are critical of her or his own institution or of some other powerful institution or group. University authorities are frequently less tolerant of these sorts of criticism than previously, and much more sensitive to external reactions that may affect a university's public reputation, and thereby its capacity to attract research funds and students.

Another threat to academic freedom of this kind stems from rising concern with the 'war on terror' since 9/11 (Doumani 2006, Gerstmann \& Streb 2008, O'Neil 2008, Scott 2014). In the UK, especially, serious threats to the principle of free speech have arisen from the efforts of successive governments to stem the radicalization of Muslim youth. In particular, since 2001, universities are increasingly seen not as places in which the vigorous debate should be encouraged but as places where there is a threat of extremists gaining a platform and brainwashing susceptible students into joining radical groups. This has led to demands that speakers at events held on university premises be carefully vetted. It has also led to requirements that universities check on the employability status of external examiners, and closely monitor the whereabouts and activities of international students. In 2014, these demands were intensified. Under a new terrorist bill, developed by the Coalition government, there was to be a legal duty for universities to ban radical speakers and to follow the 'guidance' issued by the Home Office for identifying such speakers on campuses. If they failed to follow it, the government would issue universities with 'directions'. Commenting on the proposed new bill, Scott (2014) wrote 'There is no confidence that, in the battle of ideas, values of openness, tolerance and liberty — those much lauded "British" values — will triumph, so we must be closed, intolerant and authoritarian (rather like the extremists we seek to oppose?)' (www.theguardian.com/education/2014/dec/02/antiterror-measures-make-us-extremists, accessed 11/12/ 2014). In February 2015, and as a result of a successful campaign organized by a large number of UK academics, the Government was forced to exempt universities from this legal obligation.

These developments can also affect what academics do in their research and teaching, for example by increasing the risks associated with particular topics. 
One example is the University of Nottingham calling in the police because a member of staff had downloaded the al-Qaeda Training Manual, something freely available on the Internet and on US government web sites (Nilsen et al. 2008). Such incidents are sure to increase, and the effect may be to dissuade academics from dealing with sensitive topics, to the detriment of their work.

I have shown in this paper that in the UK academic freedom has become much more constrained. Unfortunately, it seems likely that many of the trends discussed are set to continue, threatening the quality of the work that is done in universities and the contribution of university education to a free society.

Acknowledgements. I thank the 3 thoughtful referees for their comments and suggestions.

\section{LITERATURE CITED}

Arblaster A (1973) Academic freedom. Penguin, Harmondsworth

Arthur J (2006) Faith and secularisation in religious colleges and universities. Routledge, London

Broadbent J, Dietrich M, Roberts J (eds) (1997) The end of the professions? The restructuring of professional work. Routledge, London

Butler J (2006) Israel/Palestine and the paradoxes of academic freedom. Radic Philos 135:8-17. www.egs.edu/ faculty/judith-butler/articles/israel-palestine-paradoxesof-academic-freedom/

Collier D, Hidalgo F, Maciuceanu A (2006) Essentially contested concepts: debates and applications. J Polit Ideologies 11:211-246

Collini S (2012) What are universities for? Penguin, London

Doumani B (2006) Academic freedom after September 11. MIT Press, Cambridge, MA

Fish S (2014) Versions of academic freedom. University of Chicago Press, Chicago, IL

Freidson E (1983). The theory of the professions: the state of the art. In: Dingwall R, Lewis P (eds) The sociology of the professions. Macmillan, London, p 19-37

Gerstmann E, Streb MJ (2008) Academic freedom at the dawn of a new century: how terrorism, governments and culture wars impact free speech. Stanford University Press, Stanford, CA

Goldberg M (2013) What does the American Studies Association's Israel boycott mean for academic freedom? The Nation, December 6. www.thenation.com/blog/177499/ what-does-american-studies-associations-israel-boycottmean-academic-freedom\#

Hammersley M (2009) Against the ethicists: on the evils of ethical regulation. Int J Soc Res Methodol 12:211-225

Hammersley M, Traianou A (2011) Moralism and research ethics: a Machiavellian perspective. Int $\mathrm{J}$ Soc Res Methodol 14:379-390

Hammersley M, Traianou A (2012) Qualitative research ethics: controversies and contexts. Sage, London

Haskell LT (1996) Judging the rights of academic freedom in the era of power/knowledge. In: Menand L (ed) The future of academic freedom. University of Chicago Press, Chicago, IL, p 43-91

Hayes D (2009) Academic freedom and the diminished subject. Br J Educ Stud 57:127-145

$>$ Holmwood J (2010) Sociology's misfortune: disciplines, interdisciplinarity and the impact of audit culture. Br J Sociol 61:639-658

Holmwood J (ed) (2011) A manifesto for the public university. Bloomsbury, London

Jones K (2015) Education in Britain, 2nd edn. Polity Press, London

Larson MS (1977) The rise of professionalism: a sociological analysis. University of California Press, Berkeley, CA

McGettigan A (2013) The great university gamble. PlutoPress, London

McGettigan A (2014) Uncontrolled expansion: how private colleges grew. www.timeshighereducation.co.uk/ features/uncontrolled-expansion-how-private-collegesgrew/2016579.article

McNay I (1995) From collegial academy to corporate enterprise: the changing cultures of universities. In: Schuller T (ed) The changing university? SRHE/Open University Press, Buckingham, p 22-40

Menand L (1996) The limits to academic freedom. In: Menand L (ed) The future of academic freedom. Chicago University Press, Chicago, IL, and London, p 3-20

Middlehurst R (2004) Changing internal governance: a discussion of leadership roles and management structures in UK universities. High Educ Q 58:258-279

Middlehurst R, Kennie T (1995) Leadership and professionals: comparative frameworks. Tertiary Educ Manag 1: 120-130

Nilsen AG, Pupavac V, Renz B (2008) The Nottingham Two and the War on Terror: Which of us will be next? Times Higher Education Supplement, 5 June. www.timeshigher education.co.uk/402258.article

O'Neil RM (2008) Academic freedom in the wired world: political extremism, corporate power, and the university. Harvard University Press, Cambridge, MA

Pollitt C (1993) Managerialism and the public services: the Anglo-American experience. Blackwell, Oxford

Pollitt C (2003) The essential public manager. Open University Press, Maidenhead

Post R (2006) The structure of academic freedom. In: Doumani B (ed) Academic freedom after September 11. Zone Books, Brooklyn, NY

Power M (1999) The audit society: rituals of verification. Oxford University Press, Oxford

Radice H (2013) How we got here: UK higher education under neoliberalism. ACME Int E-J Crit 12:407-418

Robbins Lord (1966) Of academic freedom. Thank-offering to Britain fund lectures. Proc Br Acad 52:45-60

Robin C (2014) But for the boycott there will be academic freedom. http://coreyrobin.com/2014/02/06/but-for-theboycott-there-would-be-academic-freedom/

Russell C (1993) Academic freedom. Routledge, London

Sayer D (2014a) Protest for a REFormation. Times Higher Education Supplement, December 11, p. 38, http://www. timeshighereducation.co.uk/11-december-2014/2017480. article

Sayer D (2014b) Rank hypocrisies: the insult of the REF. Sage, London

Scott P (1995) The meanings of mass higher education. SRHE and Open University Press, Buckingham 
Scott P (1997) The changing role of the university in the production of new knowledge. Tertiary Educ Manag 3:5-14

Scott P (2014) Anti-terror measures will make us the extremists we fear. www.theguardian.com/profile/peterscott

Shattock M, Berdahl R (1984) The University Grants Committee 1919-83: changing relationships with government and the universities. High Educ 13:471-499

Shils E (1997) The calling of education. University of Chicago Press, Chicago, IL

Sizer J (1987) Institutional responses to financial reductions in the university sector. Final Report to the DES. DES, London

Smith S (2011) Afterword: a positive future for higher educa-

Editorial responsibility: Konstantinos Stergiou, Thessaloniki, Greece tion in England. In: Holmwood J (ed) A manifesto for the public university. Bloomsbury, London, p 127-142

Strathern M (2000) Accountability and... ethnography. In: Strathern M (ed) Audit cultures: anthropological studies in accountability, ethics and the academy. Routledge, London, p 278-304

Tapper T, Salter B (1992) Oxford, Cambridge and the changing idea of the university: the challenge to donnish dominion. SRHE/Open University Press, Buckingham

Ward CS (2012) Neoliberalism and the global restructuring of knowledge and education. Routledge, London

Wolff $\mathrm{J}$ (2010) Why is the Middlesex University philosophy department closing? www.theguardian.com/education/ 2010/may/17/philosophy-closure-middlesex-university

Submitted: December 17, 2014; Accepted: March 3, 2015 Proofs received from author(s): May 8, 2015 